\begin{tabular}{|l|l|l||}
\hline \multicolumn{2}{|c|}{ PublisherInfo } \\
\hline \hline PublisherName & $:$ & BioMed Central \\
\hline \hline PublisherLocation & $:$ & London \\
\hline \hline PublisherImprintName & $:$ & BioMed Central \\
\hline \hline
\end{tabular}

\title{
Polymorphisms suggest mitochondrial recombination
}

\begin{tabular}{||l|l|l||}
\hline \multicolumn{2}{|c||}{ ArticleInfo } \\
\hline \hline ArticleID & $:$ & 3548 \\
\hline \hline ArticleDOI & $:$ & $10.1186 /$ gb-2000-1-1-reports014 \\
\hline \hline ArticleCitationID & $:$ & reports014 \\
\hline \hline ArticleSequenceNumber & $:$ & 39 \\
\hline \hline ArticleCategory & $:$ & Paper report \\
\hline \hline ArticleFirstPage & $:$ & 1 \\
\hline \hline ArticleLastPage & $:$ & 3 \\
\hline \hline & & RegistrationDate : 1999-12-17 \\
ArticleHistory & $:$ & Received \\
\hline ArticleCopyright & $:$ & BioMed Central Ltd2000 \\
\hline \hline ArticleGrants & $:$ & \\
\hline \hline ArticleContext & $:$ & 130591111 \\
\hline \hline
\end{tabular}




\section{Abstract}

The patterns of nucleotide polymorphism in human mitochondrial sequences rock the belief that mitochondria do not recombine.

\section{Significance and context}

There is a persistent belief that in animals and higher plants, mitochondria are inherited from only one parent, the female. This means that different mitochondria should never be found in the same individual, and so mitochondria cannot recombine. Working from this assumption, mitochondrial sequences have become the paradigm for inferring relationships between different human groups. By looking at patterns of DNA polymorphism, Eyre-Walker et al. have provided evidence that recombination events have occurred in the evolutionary history of human mitochondria. This means that mitochondria from sperm must sometimes enter the egg at fertilization. Conclusions about human history derived from studies of mitochondrial DNA must now be reinterpreted.

\section{Key results}

The authors used published data from 29 largely complete mitochondrial sequences, taken from humans from Europe and Africa. Nucleotide positions that vary between individuals, known as segregating sites, were used to construct trees representing the relationship between sequences. If each segregating site is the result of a single mutation, and there is no recombination, then the pattern of variation describes a unique tree. If recombination occurs, however, then different parts of the sequence will have different trees. This means that if you try to construct a single tree from sequences in which there is recombination, some segregating sites will appear to be the result of several mutations. If there is an independent estimate of the mutation rate, the number of these 'homoplasies' can be used as an indicator of the extent of recombination. Eyre-Walker and colleagues show here that the number of homoplasies in the human mitochondrial trees is difficult to explain by mutation alone and argue that recombination is the most likely explanation.

\section{Links}


For a thorough description of the statistics behind the inferring of patterns of evolution from DNA sequence data see the paper Ancestral inference from gene trees by R Griffiths, available as a Postscript file. For specifics of the test used see Maynard Smith's homoplasy test.

\section{Reporter's comments}

To claim that there is recombination in human mitochondria is close to heresy. So many studies have used mitochondrial sequences to infer patterns of population history because in the absence of recombination you can build phylogenetic trees. The notion of a mitochondrial 'Eve' is even based on the assumption that there is no recombination. This paper (and another by Hagelberg and colleagues in the same volume) provide strong evidence for recombination, but the tests used here are based on the rejection of null models, and it is an open question as to whether these patterns may also be caused by poorly understood mutational processes. It would be much more satisfying to see patterns that provide a genuine footprint of recombination.

\section{Table of links}

Proceedings of the Royal Society of London. Series B: Biological Sciences

Ancestral inference from gene trees

Maynard Smith's homoplasy test

\section{References}

1. Eyre-Walker A, Smith NH, Smith J Maynard: How clonal are human mitochondria?. Proc R Soc Lond B Biol Sci. 1999, 266: 477-483. 0962-8452 